first the expansion coefficient decreases on the hightemperature side. The second one corresponds to the temperature observed by Jaffray in his calorimetric measurement and reported as $40.5 \pm 0.5^{\circ} \mathrm{C}$. The third of such changes is the largest, and the last is the smallest. The volume change at $148^{\circ} \mathrm{C}$. is nearly 5.7 per cent of the volume at $25^{\circ} \mathrm{C}$. Numerical data of these changes and the volume change at the melting point not described here will be given elsewhere.

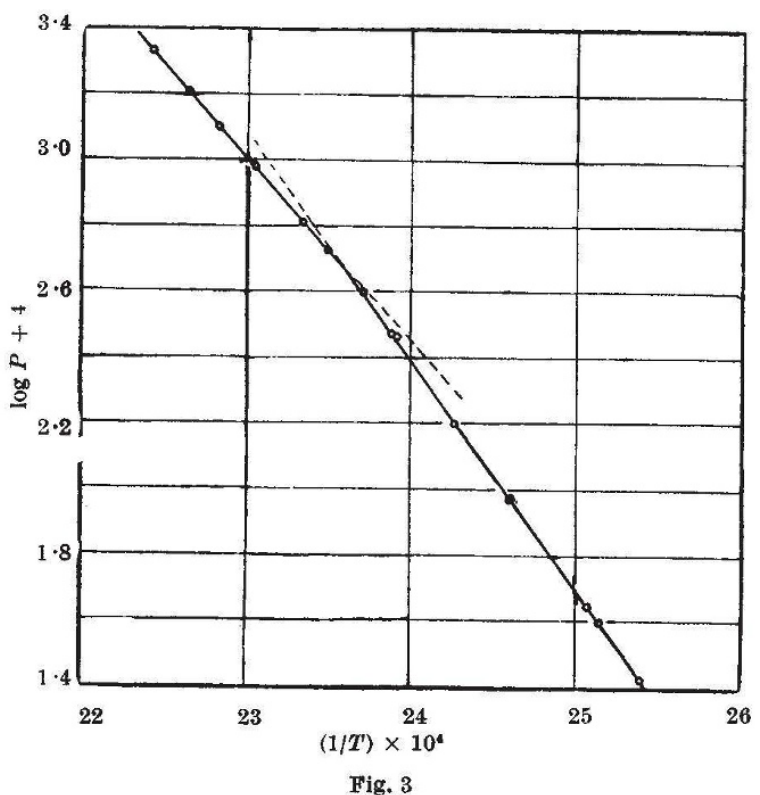

We have also measured the sublimation pressure of this substance below and above the transition points by the effusion method. The vapour pressure equation obtained below the transition point is $\log P=$ $-6934 \cdot 8 / T+15 \cdot 0299$, and above is $\log P=$ - 5922.8/T + 12.6266 (Fig. 3). From these equations, the heat of sublimation and of transition as well as the entropy changes are calculated (see table). The entropy change at the melting point is calculated by comparing the areas of the two peaks in the curve of the thermal analysis with the heat of transition obtained from the vapour-pressure measurement. These entropy data seem to explain why this substance has a very narrow range of liquid state in contrast to other members of the homologous series.

\begin{tabular}{|c|c|c|c|}
\hline$\Delta H_{\text {subl. }} \frac{\text { keal. }}{\text { mole }}$ & $\Delta H_{\text {trans. }}$ & $\begin{array}{c}\Delta s_{\text {trans. }} \\
\text { e.u. }\end{array}$ & $\Delta S_{\text {fusion }}$ \\
\hline $\begin{array}{c}31 \cdot 7 \text { (low-temp. phase) } \\
27 \cdot 1 \text { (high-temp, phase) }\end{array}$ & $4 \cdot 6$ & $11 \cdot 0$ & $11 \cdot 6$ \\
\hline
\end{tabular}

We are now attempting to measure the heat capacity of this substance. Discussion of the mechanism of this transition phenomena will be given later.
S. SEKI
M. Momotami
H. Chimara

Department of Chemistry,

Osaka University,

Osaka.

July 15.

\section{SEED STORAGE OF INDIAN FOREST PLANTS 116}

$M$ R. T. V. DENT, of the Indian Forest Service, has published splfor yaluable information on the theoretical and penctical aspects of seed storage, together with a dlscussion of the near-related principles of the Ruration of seed viability, dormancy, germinaten and the testing of seeds (Indian Forest R(ard. (Kew Series): Sylviculture, vol. 7, No. I (Mafag pr of Publications, Delhi)). In addition, an attempt is made to screen and correlate all available information on the duration of vitality and on the storage of seed of Indian forest plants.

Mr. Dent writes that it is suggested that the time is now ripe for the initiation of a carefully prepared programme of research into storage of se 3 d and near-related problems, in particular pre-sowing treatments for seeds which are difficult to germinate. Action should be initiated by the central sylviculturist, and an all-India plan of action should be devised, with the co-operation of provincial forest research officers. The shortcomings of our past methods, and the lacunæ in our knowledge of seed storage matters, are revealed by the information tabulated in this record. Here we have our starting point for planning the investigations of the future.

The monograph is divided into two parts, of which Part 1 deals with general principles relating to seed storage and is divided into nine sections covering the following: the practical importance of tree seed storage in forestry, the germination of seeds, dormancy, the duration of seed viability, the collection and extraction of tree seed, methods of seed storage, the protection of stored seed from pests, the transportation of seed and the testing of tree seed. Part 2 deals with available seed storage data for Indian forest plants and includes two tables presenting in summarized form all the principal information which is at present available on the storage and longevity of the seed of Indian forest plants.

In Great Britain it is understood how important is a knowledge of how to store seed of forest trees. It is not surprising, therefore, that India has had to consider this matter carefully, since a very much larger number of tree seeds, both indigenous and exotic, are made use of in the sub-continent of India ; at the present time, at least 20,000 acres of land are artificially afforested a year, and under new proposals this area may be very considerably enlarged.

\section{FORTHCOMING EVENTS}

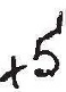
(Mestings marked with an asterisk * are open to the public)

\section{$284=$}

Monday, February 7

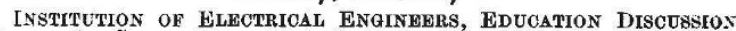
CrRcte (at Savon Place, Victoria Embankment, London, W.C.2), at 6 p.m.-Discussi 1 Place, Victoria Embankment, London, W.C.2), at Electrical Fngin is"' (to be opened by Prof. A. A. Hall and Mr. H. C. Mann).

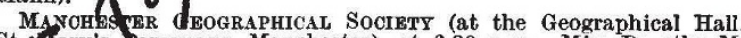
St. Mary's Parsonage, Manchester), at 6.30 p.m.-Miss Dorothy M. Sco :Southern Rhodesia and the Cape".

TEXTILE INSTITUTE (joint meeting with the SocIETr of DYERS AND COLOURISTS and the SOCIETY OF CHEYICAI INDUSTRY at $16 \mathrm{St}$ Mary's Parsonage, Manchester), at 7.15 p.m-Dr. E. S. Paice "Detergents".

Chemical Sochetr, OXford Section (in the Physical Chemistry Laboratory, Oxford), at 8.15 p.m.-Prof. C A. Coulson: "Localized Laboratory, Oxford), at 8.15 p.m.-Prof. C. A. Could
and Non-Localized Bonds" (Alembic Club Lecture).

ROYAL GEOGRAPHICAL SOCIETY (at Kensington Gore, London S.W.7), at 8.15 p.m.-Mr. A. B. Crawford : "The Life of the Tristan Islanders". 